\title{
Drop-size classification according to requirements of pesticides labels
}

\author{
Klasyfikacja rozpylenia cieczy użytkowej \\ w aspekcie wymagań etykiet środków ochrony roślin
}

\author{
Zbigniew Czaczyk
}

\section{Summary}

Presents the requirements plant protection product labels, necessitate for sprayers and nozzles. Signalized needs for determination of the spray quality and selection of spraying parameters according to plant protection product labels requirements. Illustrated and explained the method of determining the spray classes of working liquid. Explains the determination methods and the importance of the various volume drop-size fractions, and the possibilities of their selection, according to the requirements of the plant protection product label, targets, and the environmental conditions. Emphasized the need to include these issues in training and educational material for users of plant protection product. Signaled the need for mandatory verification of the nozzles for use in crop protection and the need to establish procedures for their evaluation.

Key words: spraying classification; drop-size classes; drop-size; coverage quality; plant protection product labels

\section{Streszczenie}

Przedstawiono wymagania etykiet środków ochrony roślin stawiane opryskiwaczom i rozpylaczom. Zasygnalizowano potrzebę określania jakości rozpylenia oraz doboru parametrów pracy rozpylaczy do tych wymagań. Zilustrowano i objaśniono metodę określania klas rozpylenia cieczy użytkowej. Wyjaśniono znaczenie i sposoby wyznaczania wielkości kropli, różnych objętościowych frakcji wielkości kropli oraz możliwości ich doboru odpowiednio do wymagań etykiet różnego rodzaju środków ochrony roślin, obiektów opryskiwanych i warunków środowiskowych. Podkreślono konieczność ujęcia tej tematyki w szkoleniach, materiałach szkoleniowych dla stosujących środki ochrony roślin. Zasygnalizowano konieczność urzędowej weryfikacji rozpylaczy dopuszczonych do stosowania w ochronie roślin i potrzebę ustanowienia procedur ich oceny.

Słowa kluczowe: klasyfikacja rozpylenia; kroplistość; wielkość kropli; jakość pokrycia; etykiety środków ochrony roślin

\footnotetext{
Uniwersytet Przyrodniczy w Poznaniu Instytut Inżynierii Biosystemów

Wojska Polskiego 28, 60-637 Poznań

czaczykz@up.poznan.pl
} 


\section{Wstęp / Introduction}

Instrukcje (etykiety) stosowania środków ochrony roślin (ś.o.r.) zalecają m.in. jakość rozpylenia, z jaką należy aplikować ciecz użytkową. Rozpylenie może być również określone klasą (kategoria) kroplistości i stanowi jeden $\mathrm{z}$ ważniejszych mikroparametrów pracy rozpylaczy, odpowiedzialnych za jakość pokrycia opryskiwanych obiektów. Często potocznie używa się określenia „wielkość kropli” co sugeruje, że rozpylacz wytwarza tylko krople o wielkości równej, np. medianie objętościowej Volume Median Diameter $\left(\mathrm{VMD} \equiv \mathrm{D}_{\mathrm{V} 50} \equiv \mathrm{D}_{\mathrm{V} 0,5}\right)(\mu \mathrm{m})$, a tak nie jest. Aktualnie rozróżnia się trzy różne mediany: objętościowa, liczbowa i masowa (Dorr i wsp. 2013). Żadna z median nie jest odpowiednikiem średniej średnicy kropli (Orzechowski i Prywer 2010). Inną częstą nieścisłością jest uproszczona interpretacja, że opryskujemy rozpylaczem. Jakość naniesienia cieczy użytkowej zależy od charakterystyki rozpylenia, wynikającej także z innych czynników niż cechy rozpylacza, co nie we wszystkich opracowaniach i publikacjach jest podawane i traktowane właściwie. Rozpylacze ciśnieniowe wytwarzają krople o średnicy $(\varnothing) \mathrm{w}$ zakresie od 0 do ponad $1800 \mu \mathrm{m}$, stąd parametryzacja jakości rozpylenia do potrzeb stosowania ś.o.r. za pomoca jednego wskaźnika jest nieprecyzyjna i nie jest wystarczająca. Ponadto istnieje zapotrzebowanie na zróżnicowane wielkości kropel dostosowanych do różnych wymagań ochrony (Gajtkowski 1985; Hewitt 1998; Matthews 2000). Dostawcy rozpylaczy w wyniku braku jednoznacznych norm i zaleceń (Czaczyk 2013a) parametry jakości rozpylenia określają w sposób bardzo zróżnicowany, nieprecyzyjny, niekiedy tendencyjny (Czaczyk 2012c). Z analiz obowiązujących uregulowań wynika, że traktują one tematykę techniki opryskiwania wybiórczo, np. Hołownicki i wsp. (2011). Od jakości rozpylenia zależy efektywność stosowania preparatu, a wraz z nią skuteczność biologiczna i wysokość strat (obciążenie środowiska) (Triloff 2011; Douzals 2012). Od jakości pokrycia opryskiwanych powierzchni substancją czynną zależy m.in. skuteczność biologiczna ś.o.r. Określa się ją trzema wskaźnikami: liczbą kropli na $1 \mathrm{~cm}^{2}\left(\mathrm{n}_{\mathrm{k}}\right)$, naniesieniem masy $(\mu \mathrm{g})$ na $1 \mathrm{~cm}^{2}\left(\mathrm{~m}_{\mathrm{k}}\right)$ i stopniem pokrycia powierzchni $\mathrm{s}_{\mathrm{k}}(\%)$ (Gajtkowski 1985). Wymagania te są uwzględniane przez producentów ś.o.r. w procesie ich opracowywania i zależą, np. od mechanizmu działania preparatu (mode of action). Stosowanie się do powyższych zaleceń pozwala uzyskać właściwą skuteczność. Skuteczność ochrony roślin zależy nie tylko od typu opryskiwacza, dawek cieczy użytkowej i preparatu, ale także od sposobu wykorzystania właściwości rozpylaczy, którymi należy odpowiednio (gęstość naniesienia kropli, stopień pokrycia) nanieść niezbędną ilość substancji czynnej na obiekt opryskiwany przy minimalnych stratach. Dotychczas oczekiwaną skuteczność ś.o.r. często uzyskuje się przez ich przedawkowanie, kompensując tym niedoskonałość techniczną i inne przyczyny nieprecyzyjnego (nierównomiernego) naniesienia cieczy użytkowej na powierzchnie tego wymagające. Zbyt duża dawka ś.o.r. skupiona $\mathrm{w}$ jednym miejscu, szczególnie na wrażliwych czesściach roślin, grozi fizjologicznym uszkodzeniem tkanki roślinnej (Strutyńska 1953; Triloff 2011). Translokacja substancji czynnej zależy od klasy rozpylenia i przy niewłaściwym użyciu rozpylacza przebiega niekorzystnie, gdyż preparaty kontaktowe wnikają wtedy niepotrzebnie w tkankę roślinną (więcej pozostałości ś.o.r. w produktach pochodzenia roślinnego) (Czaczyk i wsp. 2011), zaś preparaty systemiczne mogą pozostawać na powierzchni obiektów opryskiwanych - niższa efektywność ich wykorzystania (Czaczyk i Gnusowski 2007). Właśnie praca Strutyńskiej (1953) prezentuje pierwsze wskaźniki klasyfikujące krople cieczy w ochronie roślin dostępne w polskiej literaturze. Klasyfikacja jakości rozpylenia oceniana była na specjalnym obrotowym stanowisku i próbnikach papierowych. Strutyńska (1953) zaproponowała dwa wskaźniki nazwane „miernikami”: rozpylenia i zagęszczenia. Analiz i klasyfikacji jakości rozpylenia dokonuje się na podstawie wyników pomiarów średnic kropli, powstałych w trakcie procesu rozpylenia (Matthews 2000; Nuyttens i wsp. 2009; Czaczyk 2012a; Hoffmann i wsp. 2013). Najmniejsze krople: o $\varnothing 25-35 \mu \mathrm{m}$ (Hoffmann i wsp. 2013), zalecane są do zwalczania komarów (Culicidae). Do ochrony roślin pod osłonami zalecana jest frakcja o $\varnothing 50-80 \mu \mathrm{m}$, natomiast do zwalczania szkodników i patogenów w warunkach polowych frakcja o $\varnothing 80-160 \mu \mathrm{m}$, a zakres $\varnothing$ 160-260 $\mu \mathrm{m}$ wskazany jest do zwalczania chwastów (Gajtkowski 1985; Hewitt 1998; Matthews 2000). Strutyńska (1953) uzasadniła, że najwłaściwszą w ochronie roślin jest frakcja o $\varnothing 50-100 \mu \mathrm{m}$, a krople do aplikacji fungicydów nie powinny być większe od $\varnothing 117 \mu \mathrm{m}$. Zapomina się, że ochrona roślin odbywa się dzięki aplikacji cieczy użytkowej w postaci odpowiednich kropel. Tylko nieliczne publikacje w Progress in Plant Protection/ Postępy w Ochronie Roślin dotyczące opryskiwania, zawierają w metodyce szczegóły techniczne. Żadne z kilkudziesięciu opracowań o integrowanej ochronie roślin, zamieszczone na witrynie internetowej Ministerstwa Rolnictwa i Rozwoju Wsi (MRiRW) nie zawiera zalecanych informacji technicznych. Nie zwraca się na nie uwagi stosując dowolne rozpylenie $\mathrm{w}$ błędnym przekonaniu, że zastosowanie zalecanej dawki ś.o.r. w odpowiedniej ilości wody na ha jest postępowaniem wystarczającym $\mathrm{i}$ właściwym. Zdarza się to także $\mathrm{w}$ artykułach $\mathrm{i}$ rozprawach naukowych oraz w badaniach rejestracyjnych s.o.r. Dostawcy rozpylaczy i opryskiwaczy nie podaja wyczerpujących informacji niezbędnych operatorom opryskiwaczy, doradcom, kierownikom produkcji roślinnej, instruktorom, wymaganych $w$ etykietach ś.o.r. $\mathrm{Z}$ tego powodu także opracowania ośrodków doradztwa rolniczego (ODR) i publikacje firmowane przez państwowe instytucje nie zawierają tych ważnych i niezbędnych informacji. Ponadto $\mathrm{w}$ licznych artykułach czasopism branżowych oraz firmowych materiałach informacyjnych (dostawców opryskiwaczy i rozpylaczy) można znaleźć tylko wycinkowe informacje techniczne, niektóre formułowane niewłaściwie (Czaczyk 2013c). Specjaliści od ochrony roślin, nie mają odpowiednich źródeł informacji o technice ochrony, z których mogliby zaczerpnąć wiedzę do redagowanych opracowań, np. o zintegrowanej ochronie (Pruszyński i wsp. 2008; Pruszyński 2011). Taka sytuacja wynika $\mathrm{z}$ braku przepisów, zatem istnieje pilna potrzeba zajęcia się tym ważnym zagadnieniem. Wyczerpujące materiały źródłowe o jakości rozpylenia, mogą być 
opracowane tylko na podstawie przepisów obowiązujących w Polsce. Obszerne wyniki badań, przeprowadzonych w Przemysłowym Instytucie Maszyn Rolniczych (PIMR 2004), nie zostały wykorzystane do uzupełnienia informacji o rozpylaczach niezbędnych szerokiej grupie specjalistów, doradców i użytkowników, mimo że nowatorskie koncepcje i zaawansowane metody istnieją od wielu lat (Gajtkowski 1985; Triloff 2011).

W myśl przepisów za prawidłowe stosowanie ś.o.r. odpowiada operator opryskiwacza. Program i poziom obowiązkowych szkoleń oraz dostępne urzędowe materiały informacyjne nie zapewniają informacji niezbędnych do właściwego użytkowania sprzętu (Czaczyk 2012c, 2013c), mimo obowiązywania Rozporządzenia MRiRW (2013). Nie dają one także podstawowych umiejętności praktycznego doboru parametrów pracy opryskiwaczy. Dostawcy aparatury do ochrony roślin do sprzedawanych urządzeń powinni załączać wyczerpujący komplet rzetelnych informacji (instrukcja obsługi), a tak nie jest. Zawartość instrukcji obsługi powinna być urzędowo weryfikowana. Mieści się to m.in. w zakresie działania Ustawy o zwalczaniu nieuczciwej konkurencji (Ustawa 2009), lecz nie jest egzekwowane. Mimo wpływu chemicznej ochrony roślin na środowisko oraz obowiązywania Rozporządzeń MRiRW (2013) operator w zakresie pozyskiwania źródeł informacji o poprawnym doborze jakości rozpylenia pozostawiony jest sam sobie. Niejasności i nieścisłości znajdują się także w procedurach określania wymaganych parametrów, np. klas rozpylenia. W wielu materiałach informacyjnych, kalkulatorach ręcznych, internetowych i komputerach pokładowych opryskiwaczy, klasy rozpylenia podawane są bez jednoznacznych objaśnień ich znaczenia. Brakuje danych w jaki sposób je określono oraz używa się różnych barw, niezgodnych z normą ANSI/ASAE S572.1 (2009). Norma ta powstała we współpracy BCPC (British Crop Protection Council), ASABE (American Society of Agricultural and Biological Engineers) wraz z udziałem specjalistów z innych państw (m.in. Francji i RFN). Prace Komitetu Technicznego ISO - International Organization for Standardization (TC 23/SC 6/WG 13) nad nowelizacją unifikowanej metody klasyfikacji rozpylenia, mają w najbliższych miesiącach tę sytuację uregulować. Brak także dostępu do metodyki określania jakości rozpylenia zalecanych w etykietach ś.o.r., czego nie potrafią wyjaśnić instytucje odpowiedzialne za rejestrację oraz bezpieczeństwo stosowania ś.o.r., ani ich producenci. Tej ujednoliconej metodyki określania klasy rozpylenia używają także specjaliści brytyjscy, jednak bez stosowania barw (Paul Miller konsultacja osobista). Zatem norma ANSI/ ASAE S572.1. (2009) stanowi dotychczas jedyny, międzynarodowy system odniesienia do określania klas rozpylenia, który powinien być respektowany w redagowaniu informacji zamieszczanych $\mathrm{w}$ etykietach ś.o.r. Niestety niektóre publikowane materiały podają klasy rozpylenia wg nieaktualnej normy BCPC (Doble i wsp. 1985), na co należy zwracać uwagę (niespójność pojęć). Inne źródła podają klasy rozpylenia określone wg niepoprawnych metod na podstawie przybliżonych wartości odczytanych z przykładowych wykresów obo- wiązującej normy czy ustalonych w oparciu o wartości samych VMD.

\section{Parametry klasyfikacji jakości rozpylenia I Parameters for classification of spray quality}

Norma ANSI/ASAE S572.1 (2009) wyznacza sposób określania klas rozpylenia na podstawie charakterytycznych średnic: $\mathrm{D}_{\mathrm{V} 10}, \mathrm{D}_{\mathrm{V} 50}(\mathrm{VMD})$ i $\mathrm{D}_{\mathrm{V} 90}(\mu \mathrm{m})$. Często niesłusznie nazywane są one wielkościami kropli, a są to wartości wyliczane jako wielkości teoretyczne. Dochodzi także do niewłaściwej interpretacji w wyniku mylenia definicji i (podobnych) oznaczeń $\mathrm{D}_{10}$ i $\mathrm{D}_{\mathrm{V} 10}$. Z punktu widzenia efektywności aplikacji ś.o.r. użyteczne frakcje są różne i zmienne zależnie od różnych scenariuszy ochrony - zróżnicowane warunki wymagają dostosowanych do nich parametrów (Hewitt 1998; Douzals 2012; Czaczyk 2013a). Badania z użyciem ś.o.r. są kosztowne i w niewielu laboratoriach są warunki do prowadzenia badań kroplistości na oryginalnych cieczach użytkowych. Zakres optymalnych (do aplikacji) wielkości kropli wynika także z przeznaczenia (fungicyd, herbicyd, insektycyd, inne) i sposobu działania ś.o.r. (kontaktowy, systemiczny) oraz stosowania dodatków (nawozów, kondycjonerów, surfaktantów). Z powyższego wynikają różne konsekwencje odnośnie jakości rozpylenia cieczy użytkowej i translokacji substancji czynnej (Hewitt 1998; Miller i Tuck 2005; Czaczyk i Gnusowski 2011; Czaczyk 2012c, 2013a; Dorr i wsp. 2013).

Ważnym i niedocenianym zagadnieniem jest charakterystyka obiektów chronionych lub zwalczanych, jak np.: małe, wąskie liście i źdźbła, małe pąki, szkodniki pod liśćmi, komary, na które powinna dotrzeć wymagana dawka preparatu. W tym zakresie duży problem dla środowiska stanowią rozpylacze eżektorowe grubokropliste, propagowane w sposób nieuzasadniony jako rozpylacze o skuteczności równej rozpylaczom Standardowym. Taka sama objętość cieczy użytkowej rozpylona grubokropliście da wielokrotnie mniejszą liczbę generowanych kropel niż z tej samej objętości możemy ich uzyskać $\mathrm{z}$ zastosowaniem rozpylaczy standardowych o drobniejszym rozpyleniu. Mniejsza liczba kropel nie pozwala uzyskać wymaganej gęstości na licznych, niewielkich (wąskich) opryskiwanych obiektach (Strutyńska 1953), a skuteczność uzyskuje się wtedy przeważnie dzięki zwiększonej dawce (wyższej niż niezbędna), doprowadzając do miejscowego przedawkowania substancji czynnej (ryzyko fitotoksyczności, nadmierne pozostałości ś.o.r. i koszty ochrony). Sytuacja komplikuje się jeszcze bardziej, gdy krople pod wpływem działania różnych czynników (właściwości fizyczne cieczy i/lub efektu Venturi'ego) zawierają pęcherzyki powietrza (Miller i Tuck 2005; Guler i wsp. 2007; Dorr i wsp. 2013; Szulc i Czaczyk 2013). Jednak, jak donoszą Guler i wsp. (2007), niewiele cieczy wykazuje zdolność wytwarzania pęcherzyków powietrza w kroplach (Szulc i Czaczyk 2013). Dorr i wsp. (2013) wykazali, że dawka masy cieczy użytkowej rozpylaczami eżektorowymi w wyniku powstawania pęcherzyków powietrza w kroplach może 
być do $20 \%$ niższa od dawki objętościowej dla różnych cieczy. Powstawanie pęcherzyków powietrza w kroplach różnych cieczy jest więc zróżnicowane, ich liczba, gęstość i wielkość są różne, co przekłada się na jakość rozpylenia i prędkość kropel (Dorr i wsp. 2013). Także temperatura cieczy niższa o ponad $5^{\circ} \mathrm{C}$ od temperatury powietrza, jak wykazali Miller i Tuck (2005), może skutkować istotną różnicą w jakości rozpylenia. Kolejną cechą szczególną, zmienną wraz ze wzrostem wielkości kropli, jest utrata kształtu kulistego powyżej średnicy $500 \mu \mathrm{m}$. Tym bardziej zagadnienie charakterystyki spektrum wytwarzanych kropli, jak i znaczenie klas rozpylenia, powinno być włączone do programu szkoleń i materiałów dydaktycznych oraz wymagane w instrukcjach obsługi opryskiwaczy i firmowanych przez państwowe instytucje informatorach użytkowania rozpylaczy (Czaczyk 2012c, 2013a). Brak ujęcia tak ważnych zagadnień w Krajowym planie działania (MRiRW 2012) nie sprzyja poprawie sytuacji w tym zakresie. Jakość rozpylenia cieczy i struktura pokrycia nią roślin może także mieć wpływ na dynamikę nabywania odporności agrofagów na substancje czynne. Świadome i profesjonalne podejście do jakości rozpylenia ś.o.r. stanowi duży i realny potencjał do realizacji założeń integrowanej ochrony roślin, w tym poprawy bezpieczeństwa i efektywności ich stosowania oraz redukcji zużycia i strat.

\section{Metodyka określania klas rozpylenia / Method of spray classes determination}

Klasyfikację rozpylenia należy przeprowadzać w serii badań zawierających zestaw certyfikowanych rozpylaczy referencyjnych (ANSI/ASAE S572.1 2009). Zestaw ten jest ściśle określony, co do typu rozpylaczy, kątów strumieni, wydatków jednostkowych i ciśnień. Wartości uzyskane dla tego zestawu rozpylaczy w warunkach laboratorium oceniającego służą do określania klas rozpylenia. W zakresie tej oceny wspomniana norma stawia sześć wymagań wykonania pomiarów (pkt. 5.3.):

- tym samym urządzeniem (egzemplarz),

- taką samą metodą pomiaru,

- taką samą metodą próbkowania wyników,

- taką samą metodą odczytu,

- ten sam operator,

- zbliżone warunki środowiskowe wykonywania pomiaru.

Wartości średnie charakterystycznych średnic $\mathrm{Z}$ co najmniej trzech powtórzeń: $\mathrm{D}_{\mathrm{V} 10}, \mathrm{D}_{\mathrm{V} 50}, \mathrm{D}_{\mathrm{V} 90}(\mu \mathrm{m})$ (rys. 1), uzyskane dla rozpylaczy referencyjnych, powiększone o wartości odchyleń standardowych, stanowią punkty wyznaczające krzywe referencyjne rozgraniczające klasy (rys. 2). Z uwagi na udokumentowane ryzyko wpływu temperatury cieczy niższej od temperatury otoczenia o $\Delta \mathrm{t}>5^{\circ} \mathrm{C}$ na jakość rozpylenia (Miller i Tuck 2005), czynnik ten należy brać pod uwagę (również w praktyce) stosując się do ogólnego wymogu ,zbliżonych warunków środowiskowych", ujętego w pkt. 5.3. normy. Najprostsza i najszybsza metoda oceny spektrum wielkości kropli polega na dyfrakcji wiązki światła lasera (urządzenia Malvern i Sympatec). W zależności od wyposażenia (soczewki) możliwe są pomiary w różnych zakresach wielkości kropel. Dla potrzeb typowej ochrony roślin wystarczający jest zakres $\varnothing 0,5-1500 \mu \mathrm{m}$. Definicje tzw. „średnic charakterystycznych" brzmią następująco: $\mathrm{D}_{\mathrm{V} 10}$ $(\mu \mathrm{m})$ to teoretyczna (wyliczana) wielkość kropli, względem której $10 \%$ rozpylanej objętości, stanowią krople od niej mniejsze; $\mathrm{D}_{\mathrm{V} 90}(\mu \mathrm{m})$ to teoretyczna wartość, względem której 90\% rozpylanej objętości cieczy stanowią krople od niej mniejsze (rys. 1); $\mathrm{D}_{\mathrm{V} 50}$ (inaczej VMD) to wartość względem której 50\% rozpylonej objętości stanowią krople od niej większe, a pozostałe $50 \%$ to krople

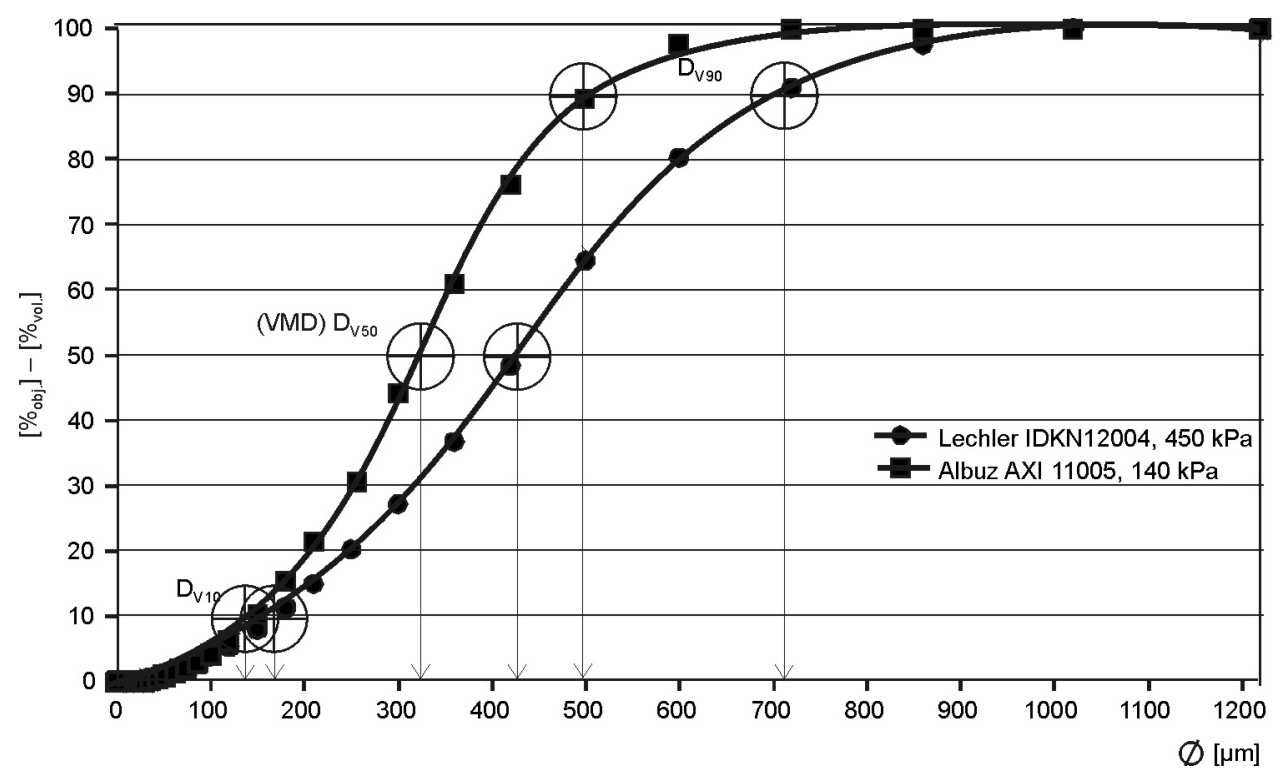

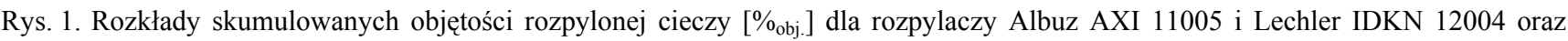
średnice charakterystyczne $\mathrm{D}_{\mathrm{V} 10}, \mathrm{D}_{\mathrm{V} 50}(\mathrm{VMD})$ i $\mathrm{D}_{\mathrm{V} 90}[\mu \mathrm{m}]$

Fig. 1. Cumulative volumetric distribution of spray liquid [\% $\%_{\text {vol.] }}$ for nozzles Albuz AXI 11005 and Lechler IDKN 12004, and characteristics diameters $\mathrm{D}_{\mathrm{V} 10}, \mathrm{D}_{\mathrm{V} 50}(\mathrm{VMD})$, and $\mathrm{D}_{\mathrm{V} 90}[\mu \mathrm{m}]$ 
od niej mniejsze. Rysunek 1. ilustruje wyniki badań własnych autora uzyskanych według normy ANSI/ASAE S572.1. (2009). Określaniem frakcji przydatnych do różnych zastosowań rolniczych w Polsce zajmowali się Strutyńska (1953) i Gajtkowski (1985). Z punktu widzenia efektywności działania ś.o.r. są to nadal aktualne zakresy wielkości kropli. Jakość rozpylenia poza czynnikami technicznymi można zmieniać poprzez modyfikację właściwości cieczy użytkowej (Miller i Tuck 2005), poprawiając $w$ ten sposób jakość pokrycia i skuteczność ś.o.r. Postęp w technice i zaostrzanie wymagań bezpieczeństwa stosowania ś.o.r. sprawiły, że konieczne jest uwzględnianie potencjału strat i ryzyka dla środowiska (Parkin i wsp. 1994; Hewitt 1998; EN-PN 2003; Miller i Tuck 2005; Czaczyk 2013b). Skutkuje to nowymi potrzebami i możliwościami poszukiwań metod doboru parametrów rozpylenia odpowiednich dla różnych właściwości: cieczy użytkowych, opryskiwanych obiektów i warunków środowiskowych (tzw. scenariuszy). Fabryczne wyposażenie opryskiwaczy (rodzaj rozpylaczy), często wynika $\mathrm{z}$ umów handlowych pomiędzy producentem opryskiwacza a dostawca rozpylaczy i nie zawsze umożliwia optymalne dopasowanie typów rozpylaczy do potrzeb użytkownika. Brak jest wyczerpujących i rzetelnych informacji o jakości pracy rozpylaczy. Rynek części zamiennych, na którym dostępne są rozpylacze (także o złej jakości), nie jest w Polsce w żaden urzędowy sposób weryfikowany (Czaczyk 2012a, c; Czaczyk i Szulc 2012). Zdarza się, że rozpylacze i opryskiwacze uzyskuja wyróżnienia i nagrody, bez kompletu zweryfikowanych informacji niezbędnych operatorowi i wymaganych w etykietach ś.o.r. oraz normach (Czaczyk 2013c). Jakość rozpylaczy, w tym charakterystyka pracy (Czaczyk 2012a), powtarzalność parametrów pracy i trwałość (Czaczyk i Szulc 2012), jak i informacje konieczne użytkownikowi (zalecenia użytkowania i klasy rozpylenia) w tak ważnej kwestii (ryzyka dla środowiska, operatora i konsumenta) pozostają bez merytorycznej kontroli. Nie jest w Polsce respektowana norma PN-EN-12761-2 (2003) (pkt. 4.3.2.) najłatwiejsza do wdrożenia metoda w zakresie kontroli ryzyka znoszenia cieczy użytkowej (Czaczyk 2013c). Nie wspomina się o niej w interpretacji przepisów unijnych (Hołownicki i wsp. 2011). Rozpylacze eżektorowe są propagowane jako redukujące znoszenie m.in. dzięki „napowietrzaniu kropli”, choć efekty redukcji znoszenia można uzyskać nie tylko za ich pomocą (Guler i wsp. 2007). Wielu badaczy udowodniło także, że kosztem redukcji znoszenia cieczy (stosowanie większych i cięższych kropli), dochodzi do znacznie wyższych strat cieczy w postaci osiadania jej na podłożu (Hewitt 1998; Triloff 2011). Rozpylenie grubokropliste może powodować m.in. niepotrzebny, nadmierny poziom pozostałości w płodach rolnych (Czaczyk i Gnusowski 2007). Priorytetem powinny pozostać skuteczność biologiczna i redukcja strat cieczy (w tym znoszenia), co jest zbieżne $\mathrm{z}$ potrzebami zmniejszenia zużycia ś.o.r. i podnoszenia bezpieczeństwa ich aplikacji (Rozporządzenie MRiRW 2013). Redukcja znoszenia, bardzo popularna $w$ ostatnich latach i promująca w uproszczonej formie rozpylacze eżektorowe, sama w sobie nie jest celem zbieżnym z tymi założeniami, gdyż jest osiagana kosztem zwyżki strat na podłożu. Jak wykazali Guler i wsp. (2007) porównywanie rozpylaczy różnych konstrukcji przy równym ciśnieniu nie jest zasadne, a dla praktyków dezinformujące, gdyż jakość rozpylenia i podatność na znoszenie, zależy od powierzchni przekroju otworu wylotowego, wydatku cieczy i jej właściwości (Hewitt 1998; Miller i Tuck 2005; Guler i wsp. 2007; Nuyttens i wsp. 2009; Dorr i wsp. 2013). Zdarza się, że to samo źródło podaje w dwóch opracowaniach różne klasy rozpylenia dla identycznego przypadku. Klasy rozpylenia można ustalać dla różnych wartości ciśnienia, a nawet dla różnych cieczy (o właściwościach zbliżonych do cieczy użytkowej), co np. w Australii jest praktykowane dla rzeczywistych cieczy użytkowych, w tym mieszanin różnych ś.o.r. i innych dodatków (Dorr i wsp. 2013). Intencją niniejszego artykułu jest wyjaśnienie procedur określania parametrów wymaganych w etykietach ś.o.r. na przykładzie przeprowadzonej serii badań własnych autora oraz przybliżenie właściwego sposobu lepszego wykorzystania charakterystyk rozpylaczy w praktyce.

\section{Badania własne, przykłady i uwagi praktyczne / Own study, examples and practical suggestions}

W celu rzetelnego wyjaśnienia właściwego określania klas jakości rozpylenia autor wykonał serię badań według zaleceń normy ANSI/ASAE S572.1. (2009). Rysunek 2. ilustruje krzywe referencyjne uzyskane w badaniach własnych autora łączące wartości charakterystycznych średnic $\left(\mathrm{D}_{\mathrm{V} 10}, \mathrm{D}_{\mathrm{V} 50}\right.$ i $\left.\mathrm{D}_{\mathrm{V} 90}\right)$ powiększone o wartość odchylenia standardowego. Rozgraniczają one klasy rozpylenia określone wg ANSI/ASAE S572.1. (2009). Wyznaczają one odpowiednio zakresy klas jakości rozpylenia: VF - very fine (bardzo drobne), $\mathrm{F}$ - fine (drobne), $\mathrm{M}$ - medium (średnie), $\mathrm{C}$ - coarse (grube), VC very coarse (bardzo grube), XC - extremely coarse (ekstremalnie grube). W tej samej serii pomiarów zgodnie $\mathrm{z}$ wymaganiami tej normy, w ten sam sposób oceniono rozpylacze płaskostrumieniowe: standardowy Albuz AXI 11005 i eżektorowy Lechler IDKN 12004. Wydatki rozpylaczy wynosiły odpowiednio: 1,94 1/min (Lechler) $(p=450 \mathrm{kPa})$ i 1,40 l/min (Albuz) $(p=140 \mathrm{kPa})$. Pomiary wykonano za pomocą urządzenia Sympatec Helos Vario, podobnie jak w pracy Czaczyka (2012b), stosując wodę wodociągową o temperaturze nie różniącej się od temperatury otoczenia o więcej niż $3^{\circ} \mathrm{C}$. Z uwagi na zastosowanie metody dyfrakcji wiązki światła laserowego badania przeprowadzono $\mathrm{w}$ strumieniu powietrza o prędkości około $6,7 \mathrm{~m} / \mathrm{s}$. Badane rozpylacze przemieszczano w odległości około $30 \mathrm{~cm}$ od wiązki światła, pionowo w dół z prędkością około $15 \mathrm{~cm} / \mathrm{s}$, prostopadle do wiązki światła i kierunku podmuchu powietrza (Czaczyk 2012b). Charakterystyczne średnice zmierzone dla rozpylenia uzyskanego $\mathrm{z}$ tych rozpylaczy zostały wprowadzone do danych źródłowych, co jako dodatkowe krzywe pokazano na rysunku 2. Wyniki testu pozwoliły zakwalifikować rozpylenie rozpylacza Lechler IDKN 12004 do klasy VC (bardzo grube), gdyż wszystkie trzy średnice charakterystyczne: $\mathrm{D}_{\mathrm{V} 10}, \mathrm{D}_{\mathrm{V} 50} \mathrm{i} \mathrm{D}_{\mathrm{V} 90}$, znalazły się w zakresie tej klasy. Trudność $\mathrm{w}$ jednoznacznym określeniu klasy rozpylenia 
stwarzają wartości charakterystycznych średnic $\mathrm{D}_{\mathrm{V} 10}$ i $D_{\mathrm{V} 50}$, uzyskane dla rozpylacza Albuz AXI 11005. Wartość $D_{\mathrm{V} 10}$ była wyższa od wartości referencyjnej klasy $\mathrm{M}$ - średnie, czyli mieściła się w zakresie klasy $\mathrm{C}$ - grube. Natomiast wartości $\mathrm{D}_{\mathrm{V} 50}$ i $\mathrm{D}_{\mathrm{V} 90}$, znalazły się w zakresie klasy M - średnie. Sytuacje takie nie są rzadkością. Wartość $D_{\mathrm{V} 90}$, jest uznawana za mniej znaczącą przy określaniu klas kroplistości, co ma być uwzględnione w opracowywanej normie (ISO-EN) dotyczącej zmodyfikowanej klasyfikacji rozpylenia. Dobór parametrów pracy rozpylaczy w ochronie roślin ma charakter złożony. Niektóre źródła wykazują, że znaczenie w klasyfikacji jakości rozpylenia (szczególnie w zakresie podatności na znoszenie i odparowanie) ma objętość frakcji kropli mniejszych od $\varnothing 75 \mu \mathrm{m}\left(\mathrm{V}_{<75}\right)\left(\%_{\text {obj. }}\right)$ (Nuyttens i wsp. 2009).

Określenie klasy rozpylenia, ani wartości $\mathrm{D}_{\mathrm{V} 10}, \mathrm{D}_{\mathrm{V} 50}$ i $\mathrm{D}_{\mathrm{V} 90}$ nie dają pełnego wglądu we właściwości spektrum generowanych kropli, a tym samym możliwości pełnego wykorzystania cech rozpylaczy w konkretnych warunkach. Dla wnikliwszego przedstawienia sytuacji sporządzono kolejne wykresy (rys. 3, 4). Na rysunku 3. zilustrowano spektrum kropli $(\varnothing 0-1220 \mu \mathrm{m})$, podzielone na 25 frakcji objętościowych. Z takich danych wyjściowych, uzyskanych dzięki oprogramowaniu urządzeń pomiarowych, można dowolnie tworzyć różne frakcje w poszukiwaniu właściwych informacji o charakteryzowanych rozpyla- czach. Na rysunku 4. zilustrowano przykładowy udział frakcji skumulowanych do trzech najważniejszych przedziałów średnic, $\mathrm{z}$ możliwością wglądu w ich proporcje. Frakcja kropli o $\varnothing 0-100 \mu \mathrm{m}, \mathrm{V}_{<100}\left(\%_{\text {obj. }}\right)$ uznawana jest za wskaźnik podatności na znoszenie, mimo że krople z przedziału $\varnothing 80-100 \mu \mathrm{m}$, uważane są za bardzo efektywne w ochronie (Strutyńska 1953; Gajtkowski 1985; Matthews 2000). Należy pamiętać, że ich wysoka efektywność może być bezpiecznie wykorzystana w optymalnych warunkach środowiskowych, tj.: przy prędkości wiatru $0,5-2,0 \mathrm{~m} / \mathrm{s}$ i niskim deficycie wilgoci w powietrzu. Ocenę przydatności warunków środowiskowych (relację wilgotności i temperatury powietrza), w użyteczny dla praktyki sposób, przedstawia broszura Nufarm (2004). Niektórzy specjaliści zajmujący się techniką aplikacji ś.o.r. uznaja, jak podali m.in. Gajtkowski (1985) i Matthews (2000), że wraz z rosnąca wielkością kropli ( $>\varnothing 160 \mu \mathrm{m}$ ), efektywność wykorzystania cieczy znacznie maleje. $Z$ tej samej objętości cieczy powstaje mniejsza liczba większych kropli lub większa liczba mniejszych kropli. Stosowanie drobniejszego rozpylenia pozwala lepiej (gęściej i równomierniej) pokryć opryskiwaną powierzchnię mniejszą objętością cieczy użytkowej - lepsza efektywność agrotechniczna (mniej napełnień opryskiwacza mniejsze zużycie wody $(<100$ 1/ha), krótszy czas wykonania ochrony, przy wyższym stężeniu

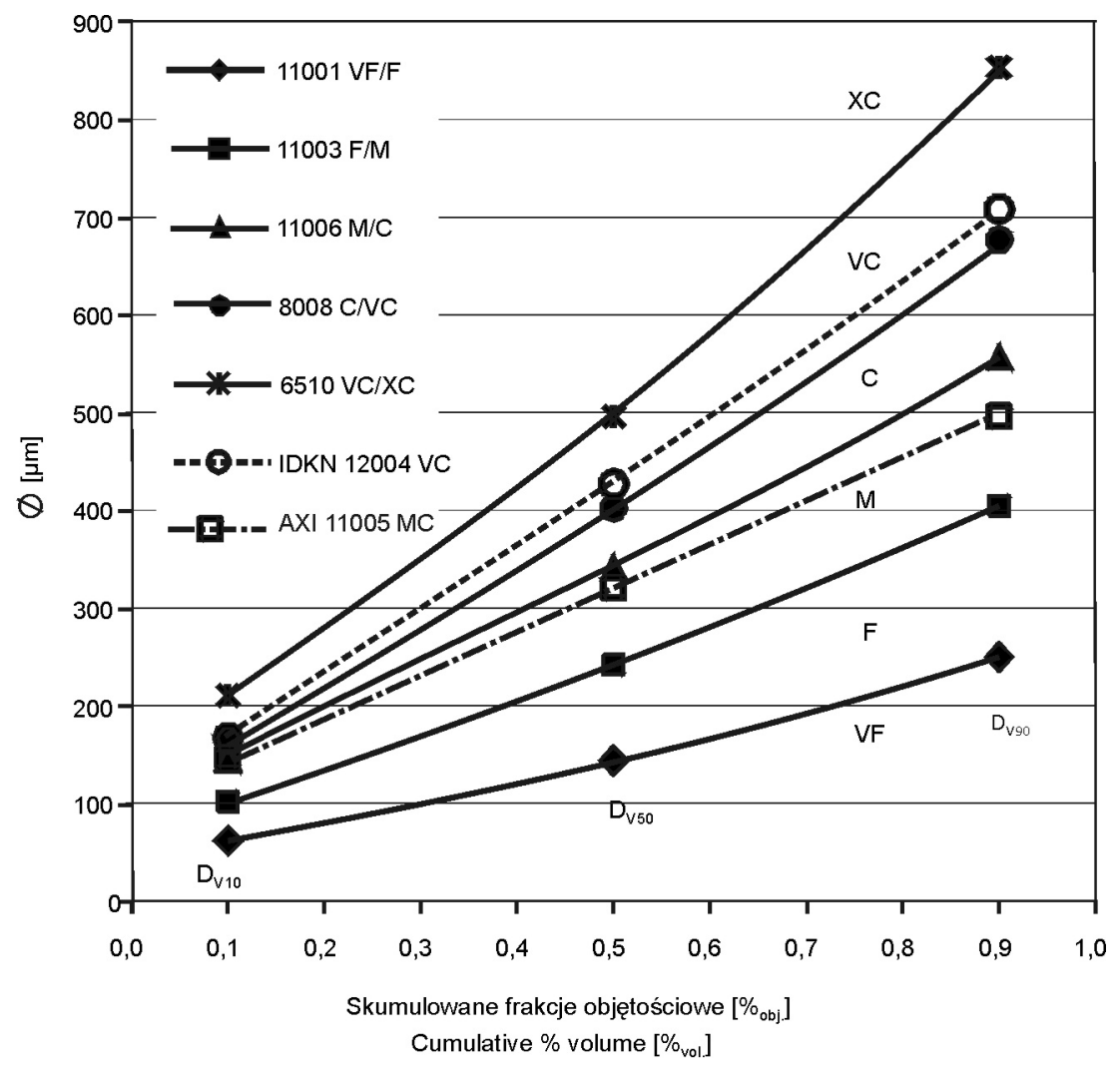

Rys. 2. Przykładowe wartości referencyjne wyznaczone według normy ANSI/ASAE S572.1. (2009) do określania klas jakości rozpylenia oraz wykresy przykładowo klasyfikowanych rozpylaczy Albuz AXI 11005 i Lechler IDKN 12004

Fig. 2. Example of reference values determined according ANSI/ASAE S572.1. (2009) standard, for spray classes classification, and these graphs as examples classified nozzles Albuz AXI 11005 and Lechler IDKN 12004 


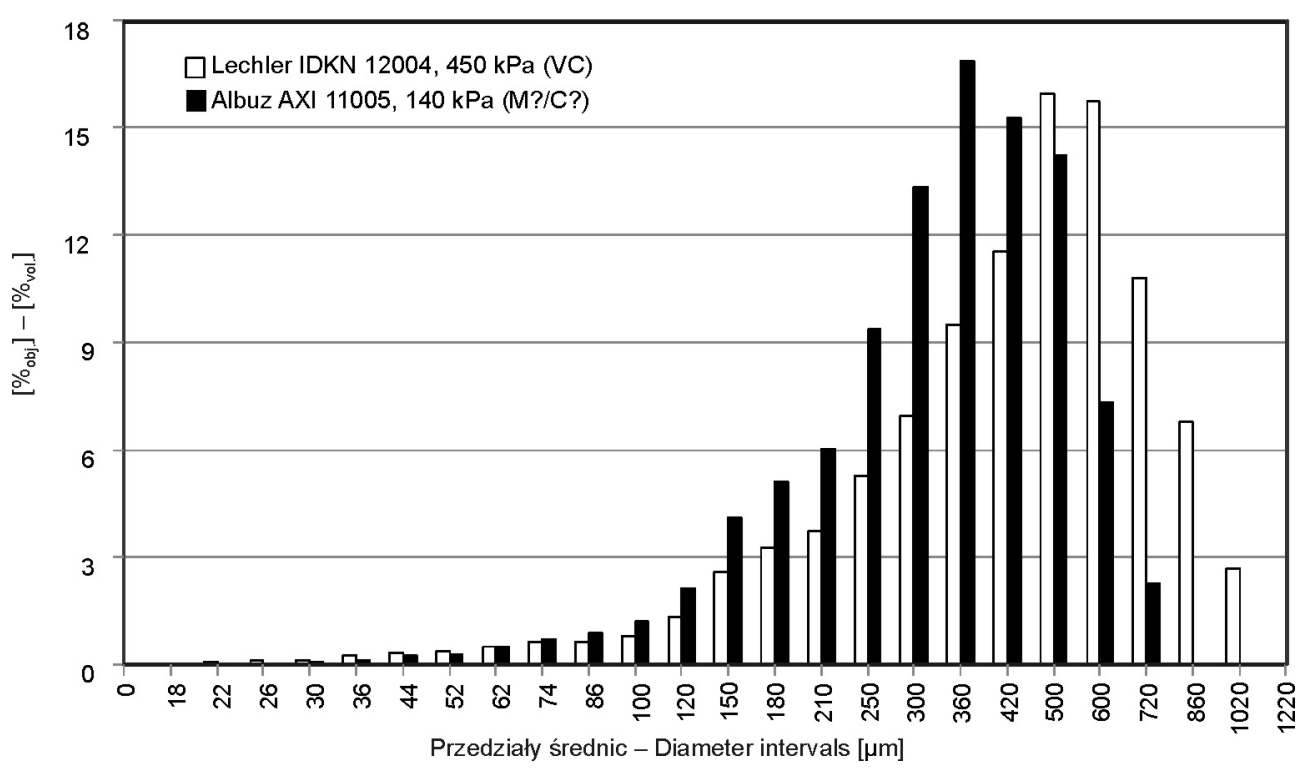

Rys. 3. Rozkłady objętości rozpylonej cieczy w poszczególnych 25 frakcjach średnic kropli dla przykładowo sklasyfikowanych rozpylaczy Lechler IDKN 12004 i Albuz AXI 11005

Fig. 3. Volumetric distribution of sprayed liquid in 25 drop-size fractions for classified as examples nozzle Lechler IDKN 12004 and Albuz AXI 11005

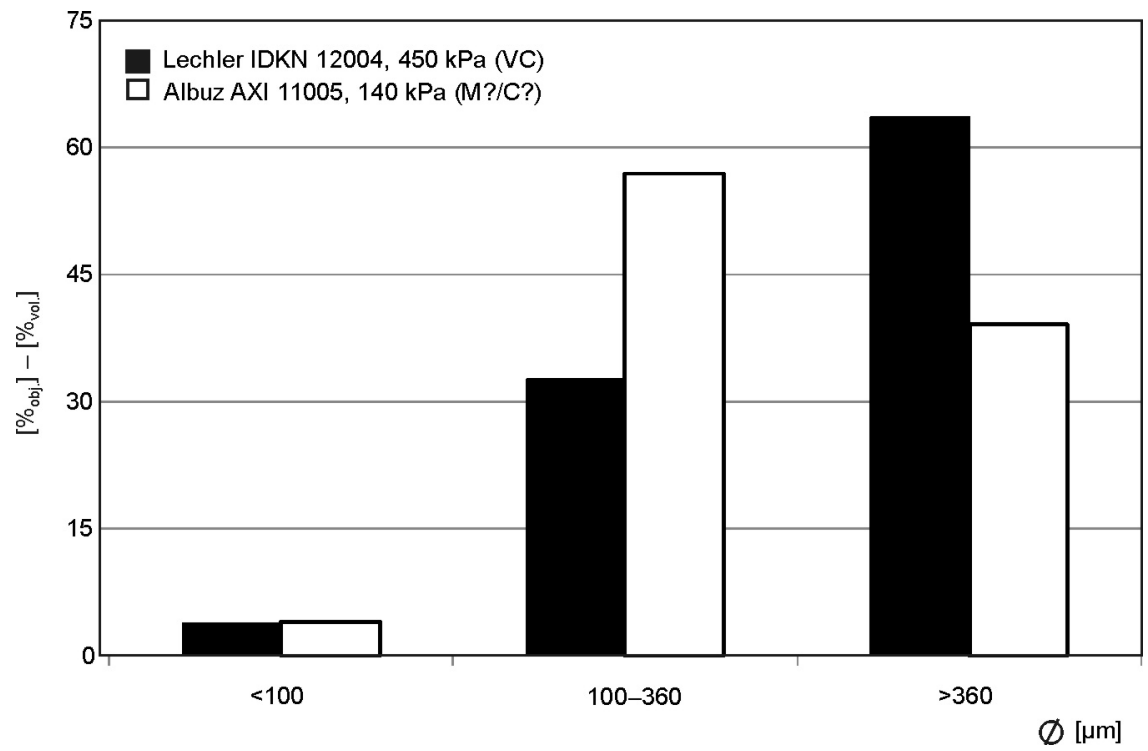

Rys. 4. Rozkłady objętości rozpylonej cieczy $w$ trzech przykładowych frakcjach $\left(\mathrm{V}_{<100}, \mathrm{~V}_{100-360}\right.$ i $\left.\mathrm{V}_{>360}\right)$ mających wpływ na efektywność i bezpieczeństwo aplikacji ś.o.r.

Fig. 4. Volumetric distribution of sprayed liquid in three example drop-size classes $\left(\mathrm{V}_{<100}, \mathrm{~V}_{100-360}\right.$, and $\left.\mathrm{V}_{>360}\right)$ influenced of application efficiency and safety

ś.o.r. (wyższa skuteczność), równocześnie z niższą dawką ś.o.r. (Czaczyk 2012a). Wykorzystanie właściwości rozpylacza, umożliwia wytworzenie większej liczby odpowiednich kropli $z$ tej samej objętości cieczy. $Z$ litra cieczy użytkowej można uzyskać około $238,7 \times 10^{6}$ kropli $\varnothing 200 \mu \mathrm{m}$ i tylko około $29,8 \times 10^{6}$ kropli $\varnothing 400 \mu \mathrm{m}$ (około ośmiokrotnie mniej). Rozkłady objętościowe przedstawione dla przykładowych przebadanych rozpylaczy o różnej konstrukcji i budowie (rys. 3, 4) pokazują w obu przypadkach podobną zawartość frakcji $\mathrm{V}_{<100}$ (około $4 \%$ wydatku) podatnej na znoszenie. Frakcje kropel do $\varnothing 62 \mu \mathrm{m}$ (rys. 3) miały większy udział objętościowy dla rozpylacza eżektorowego, co jest niekorzystne. Objętości cieczy pozostałych frakcji rozpylenia rozkładały się następująco:

- dla frakcji $>\varnothing 300 \mu \mathrm{m}\left(\mathrm{V}_{>300}\right)$ od około $73 \%{ }_{\text {obj. }}$ do około $56 \%_{\text {obj. }}$ na korzyść rozpylacza standardowego,

- dla frakcji $>\varnothing 360 \mu \mathrm{m}\left(\mathrm{V}_{>360}\right)$ od około $63 \%$ obj. do około 39\% $\%_{\text {obj. }}$ na korzyść rozpylacza standardowego.

Zatem we frakcjach korzystnych średnic kropli $\mathrm{V}_{100-300}$ i $\mathrm{V}_{100-360}$, odpowiednio rozpylano około $40 \%$ obj. i około $23 \%_{\text {obj. }}$ oraz około $57 \%_{\text {obj. }}$ i około $33 \%_{\text {obj. na korzyść }}$ 
przykładowego rozpylacza standardowego. Objętości rozpylane na frakcje korzystne, przy niższym wydatku $(1,40 \mathrm{l} / \mathrm{min}) \quad$ rozpylacza standardowego, wyniosły odpowiednio: $0,56 \mathrm{l} / \mathrm{min}$ frakcji $\mathrm{V}_{100-300} \mathrm{i} 0,80 \mathrm{l} / \mathrm{min}$ frakcji $\mathrm{V}_{100-360}$, a dla eżektorowego: 0,45 1/min frakcji $\mathrm{V}_{100-300}$ i $0,64 \mathrm{l} / \mathrm{min}$ frakcji $\mathrm{V}_{100-360}$, przy wydatku $1,94 \mathrm{l} / \mathrm{min}$.

\section{Dyskusja wyników / Results discussion}

Z uwagi na często występujące trudności w przypisaniu wyników jakości rozpylenia badanego rozpylacza do klasy jakości rozpylenia, wskazane byłoby podawanie metody, lub współczynnika wg jakiego przypisanie do klasy nastapiło. Podobną sugestię należy poczynić do producentów ś.o.r. Należy także zwrócić uwagę, że dla rozpylacza antyznoszeniowego eżektorowego, w porównanych warunkach uzyskano wyższą objętość cieczy rozpyloną we frakcji niekorzystnej, tzn. do wielkości $\varnothing 62 \mu \mathrm{m}$, w porównaniu do standardowego rozpylacza płaskostrumieniowego (rys. 3) o zbliżonym kącie rozpylenia. Podobne efekty uzyskali m.in. Nuyttens i wsp. (2009) wykazując także zbliżone efekty biologiczne uzyskane rozpylaczami standardowymi i eżektorowymi, jednak ich badania dotyczyły dość znacznych (160-320 1/ha) dawek cieczy użytkowej. Rozpylacze standardowe o mniejszym kącie rozpylenia (np. 80) wytwarzają relatywnie węższe spektrum wielkości kropli oraz jeszcze mniejszą objętość cieczy użytkowej rozpylają we frakcji $\mathrm{V}_{<100}$. Parametr kąta strumienia rozpylonej cieczy także należy brać pod uwagę $\mathrm{w}$ procesie poszukiwania metod redukcji ryzyka znoszenia i strat cieczy użytkowej. Autorytety m.in. Guler i wsp. (2007) twierdzą, że rodzajów rozpylaczy jest już za wiele, a wiedza o jakości ich pracy w odniesieniu do potrzeb i wymagań praktyki jest niewystarczająca. Opinie specjalistów zajmujących się opryskiwaniem o górnej średnicy zalecanej kropli, powyżej której ochrona roślin zdecydowanie nie jest wskazana są podzielone, ponieważ zależy to od wielu czynników. Warunki pogodowe podczas wykonania ochrony są różne i zmienne, wymagania w zakresie bezpieczeństwa aplikacji (redukcji znoszenia) w różnych krajach (np. Holandia, Niemcy, Polska, USA) są zróżnicowane i zaostrzane. Informacje zawarte na rysunkach 3. i 4., dzięki frakcjom np. $\mathrm{V}_{100-360}$, umożliwiają wybór odpowiednich parametrów do sytuacji (scenariusza), lepsze wykorzystanie rozpylaczy oraz cieczy użytkowej (herbicyd lub inny ś.o.r.), jak również bezpieczniejszą aplikację (dla środowiska, płodów rolnych i operatora).

\section{Wnioski / Conclusions}

1. Właściwa interpretacja wymagań podawanych w etykietach ś.o.r. oraz znaczenia klas rozpylenia, powinna przyczynić się do lepszego zrozumienia wagi informacji o jakości rozpylenia, rozpylaczach oraz technice stosowania ś.o.r., jak również zasadności ich uwzględnienia w profesjonalnej, bezpiecznej i efektywnej ochronie roślin.
2. Określenie charakterystyk pracy rozpylaczy w pełnym zakresie zalecanych ciśnień roboczych według norm: ISO (1997); PN-EN (2003); ANSI/ASAE S572.1. (2009), odpowiednio do zamieszczanych informacji $\mathrm{w}$ instrukcjach stosowania ś.o.r. jest niezbędne, aby operator mógł właściwie dobierać rozpylacze i parametry pracy opryskiwacza (bezpieczna i efektywna ochrona), we właściwy sposób wykorzystywać sprzęt oraz poprawnie stosować ś.o.r.

3. Wymagania obowiązujących regulacji prawnych sugerują konieczność uporządkowania zagadnień związanych z jakością rozpylaczy dopuszczanych do stosowania ś.o.r. oraz zakresu informacji o rozpylaczach, które powinny być dostępne, w celu ich właściwego i legalnego użytkowania.

4. Należy wyeliminować podawanie przez dostawców rozpylaczy nieudokumentowanych lub niewłaściwie udokumentowanych informacji i zaleceń ich użytkowania, w tym klas rozpylenia. Rozpylacze ciśnieniowe wytwarzają bardzo szerokie i zmienne (z ciśnieniem) spektrum kropli. Stosowanie dezinformującego i uogólnionego terminu ,rozpylacz drobnokroplisty” o rozpylaczach standardowych narusza Ustawę o zwalczaniu nieuczciwej konkurencji.

5. Kompleksowo opracowane, aktualizowane i niezależnie recenzowane, szczegółowe zalecenia doboru rozpylaczy i parametrów pracy opryskiwaczy powinny być przyjęte jako integralna część opracowań nt. zintegrowanych technologii produkcji roślinnej, gdyż dotychczas brak jest takich informacji.

6. W celu pozyskania wiedzy o rozpylaczach wskazane jest utworzenie w Polsce ośrodka certyfikującego i charakteryzującego rozpylacze na wzór angielski lub niemiecki. Dotychczas sporadycznie ma to miejsce w sytuacjach takich, jak: rankingi na targach i wystawach maszyn rolniczych, gdzie niekiedy nagradzane są produkty bez wystarczającej informacji niezbędnej użytkownikowi. Opracowanie kompleksowych zaleceń o doborze parametrów pracy rozpylaczy wymaga jednak powtórzenia przekrojowych badań oraz ścisłego i efektywnego współdziałania kilku ministerstw, co jak pokazuje praktyka, nie jest łatwe do osiagnięcia.

7. Przepisy i działania organów ustanawiających regulacje dotyczące wyposażenia, działania i użytkowania urządzeń do stosowania ś.o.r. powinny być formułowane z aktywnym udziałem dostawców sprzętu, ś.o.r., a także diagnostów Stacji Kontroli Opryskiwaczy.

8. Niezbędne jest w Polsce ustalenie krajowych metod oceny charakterystyk opryskiwaczy (polowych i sadowniczych) oraz potencjałów redukcji strat cieczy (w tym znoszenia), co jest zbieżne $\mathrm{z}$ Dyrektywą 2009/128/WE obligująca kraje UE do redukcji zużycia ś.o.r. i podniesienia bezpieczeństwa ich stosowania. Kopiowanie rozwiązań zagranicznych nie jest możliwe z uwagi na duże zróżnicowanie parametrów i lokalną specyfikę opryskiwaczy użytkowanych w polskim rolnictwie. Spójny z tym przedsięwzięciem byłby proces ustalenia krajowej metodyki określania charakterystyk rozpylaczy, w tym potencjału (klas) redukcji strat cieczy użytkowej (w tym znoszenia). Producent opryskiwacza, zobligowany do redagowania instrukcji 
obsługi powinien mieć wsparcie dostawców rozpylaczy i ś.o.r. oraz instytucji odpowiedzialnych za bezpieczne stosowanie ś.o.r.

9. W integrowanej ochronie roślin do użytkowania powinny być dopuszczone wyłącznie rozpylacze $\mathrm{z}$ atestem (co najmniej ENTAM) i wyczerpującymi informacjami (niezbędnymi do właściwego stosowania ś.o.r.) o jakości ich pracy (powtarzalność wydatku, klasa rozpylenia, potencjał redukcji strat oraz znoszenia cieczy) dostosowanymi do wymagań instrukcji stosowania ś.o.r. (różnych warunków pogody i stref buforowych) z uwzględnieniem norm CEN, ISO i zaleceń FAO.

10.Z uwagi na pojawianie się nowych rozwiązań technicznych, procedur i zbyt dużej dowolności w stosowaniu określeń i nazw (często mylących), wskazana byłaby standaryzacja terminologii (nazewnictwa) oraz zalecenie weryfikacji wg niej tekstów artykułów i rozpraw naukowych, popularnonaukowych, ekspertyz, instrukcji obsługi i materiałów szkoleniowych.

\section{Literatura / References}

ANSI/ASAE S572.1. 2009. Spray Nozzle Classification by Droplet Spectra. ASABE Standards, 4 pp.

Czaczyk Z. 2012a. Charakterystyka użytkowa wybranych rozpylaczy płaskostrumieniowych do ochrony upraw polowych. J. Res. Appl. Agr. Engng 57 (2): 31-40.

Czaczyk Z. 2012b. Influence of air flow dynamics on droplet size in conditions of air assisted sprayers. Atomization Spray 22 (4): $275-282$.

Czaczyk Z. 2012c. Zarządzanie wielkością kropli - science fiction czy praktyczna konieczność? s. 138-145. W: Mat. X Konf. „Racjonalna Technika Ochrony Roślin”. Inst. Ochr. Roślin, Poznań, 14-15 listopada 2012, 187 ss.

Czaczyk Z. 2013a. Jakość rozpylenia cieczy jako element doradczy decydujący o efektywności i bezpieczeństwie ochrony roślin. Zagadnienia Doradztwa Rolniczego 1: 30-44.

Czaczyk Z. 2013b. System obowiązkowych badań stanu technicznego opryskiwaczy względem aktualnych wymagań i potrzeb. Część 1 . Technika Rolnicza Ogrodnicza Leśna 3: 25-28.

Czaczyk Z. 2013c. Propozycja klasyfikacji jakości rozpylenia, potencjału redukcji strat cieczy użytkowej i podatności na znoszenie, s. 133-139. W: Mat. XI Konf. „Racjonalna Technika Ochrony Roślin”. Instytut Ogrodnictwa, Skierniewice, 23 października 2013, 165 ss. http://sendfile.pl/103564/Czaczyk_prezentacja_XI_RTOR.mp4 [dostęp: 3.01.2014].

Czaczyk Z., Fritz B.K., Hoffmann W.C. 2014. Problems with determination of spraying characteristics. Asp. Appl. Biol. 122, Int. Adv. Pest. Appl.: 405-410.

Czaczyk Z., Gnusowski B. 2007. Comparison of fungicide residues in apple flesh depending on spraying categories. Ann. University of Craiova XXXVII/A: 554-557.

Czaczyk Z., Szulc T. 2012. Charakterystyka użytkowa i produkcyjna wybranych rozpylaczy płaskostrumieniowych. J. Res. Appl. Agr. Engng 57 (2): 52-59.

Czaczyk Z., Walorczyk S., Gnusowski B. 2011. Wstępna ocena poziomu pozostałości pestycydów w winach na krajowym rynku. s. 89-92. W: Mat. Konf. V Międzynarodowa Konferencja Winiarska. PWSZ w Sulechowie, Kalsk, 25 marca 2011,104 ss.

Doble S.J., Matthews G.A., Rutherford I., Southcombe E.S.E. 1985. A system for classifying hydraulic nozzles and other atomizers into categories of spray quality. p. 1125-1133. In: British Crop Prot. Conf. Weeds 9A-5, Brighton Metropole, UK, 18-21 November $1985,1300 \mathrm{pp}$.

Dorr G.J., Hewitt A.J., Adkins S.W., Hanan J., Zhang H., Noller B. 2013. A comparison of initial spray characteristics produced by agricultural nozzles. Crop Prot. 53 (2013): 109-117.

Douzals J.-P. 2012. Asymmetric classification of drift reducing nozzles considering frontal or lateral wind conditions. Int. Conf. Agric. Engng CIGR-AgEng2012. Spain, Valencia Conf. Centre, July 8-12, 2012, 4 pp. http://cigr.ageng2012.org/images/fotosg/tabla_137_C1501.pdf [Accessed: 3.01.2014].

FAO 2001. Guidelines on standards for agricultural pesticide application equipment and related test procedures, Vehicle-mounted and trailed sprayers, $50 \mathrm{pp}$.

Gajtkowski A. 1985. Dobór parametrów pracy rozpylaczy i opryskiwaczy polowych. Rocz. AR Poznań, Rozpr. Nauk. 151, 95 ss.

Guler H., Zhu H., Ozkan H.E., Derksen R.C., Yu Y., Krause C.R. 2007. Spray characteristics and drift reduction potential with air induction and conventional flat-fan nozzles. Trans. ASABE 50 (3): 745-754.

Hewitt A.J. 1998. The importance of nozzle selection and droplet size control in spray application. p. 75-85. The North American Conf. Pest. Spray Drift Manag. Portland, Univ. Maine, March 29-April 1, 1998, 285 pp. http://pmo.umext.maine.edu/drift/drift_proceedings.pdf [Accessed: 2.01.2014].

Hoffmann W.C., Fritz B.K., Farooq M., Czaczyk Z., Walker T.W., Hornsby J., Bonds J.A.S. 2013. Evaluation of aerial spray technologies for adult mosquito control applications. J. Plant Prot. Res. 53 (3): 222-229.

Hołownicki R., Doruchowski G., Godyń A., Swiechowski W. 2011. Technika ochrony roślin w dyrektywach UE. Inżynieria Rolnicza 4 (129): $75-84$.

ISO 1997. International standard 5682-1, 2, 3: Equipment for crop protection - Spraying equip, $31 \mathrm{pp}$.

JKI (Julius Kühn Institut) 2013. Lista certyfikowanych rozpylaczy do ochrony roślin. http://www.jki.bund.de/fileadmin/dam_uploads/_AT/ger\%C3\%A4telisten/anerkannte_Duesen/Tabelle\%20der\%20JKI\%20anerkann ten\%20Pflanzenschutzduesen.pdf [Accessed: 21.05.2013].

Matthews G.A. 2000. Pesticide Application Methods. 3rd Edn. Wiley-Blackwell, Oxford, 448 pp.

Miller P.C.H., Tuck C.R. 2005. Factors influencing the performance of spray delivery systems: A review of recent developments. J. ASTM Int. 2 (6), Paper ID JAI12900, 13 pp.

MRiRW 2012. Krajowy plan działania na rzecz ograniczenia ryzyka związanego ze stosowaniem środków ochrony roślin na lata 2013-2017, 72 ss. 
http://www.minrol.gov.pl/pol/Informacje-branzowe/Produkcja-roslinna/Ochrona-roslin/Krajowy-plan-dzialania-na-lata-2013-2017 [dostęp: 29.10.2013].

Nufarm 2004. Selecting the right Delta T condition for spraying.

http://www.spraywisedecisions.com.au/Home/Faq\#q9 [Accessed: 29.10.2013].

Nuyttens D., De Schampheleire M., Verboven P., Brusselman E., Dekeyser D. 2009. Droplet size and velocity characteristics of agricultural sprays. Trans. ASABE 52 (5): 1471-1480.

Orzechowski Z., Prywer J. 2010. Wytwarzanie i zastosowanie rozpylonej cieczy. WNT, Warszawa, 504 ss.

Parkin C.S., Gilbert A.J., Southcombe E.S.E., Marshall C.J. 1994. British Crop Protection Council scheme for the classification of pesticide application equipment by hazard. Crop Prot. 13 (4): 281-285.

PN-EN 12761-2. 2003. Maszyny rolnicze i leśne - Opryskiwacze i maszyny do nawożenia płynnymi nawozami mineralnymi - Ochrona środowiska: 2. Opryskiwacze polowe, 19 ss.

PIMR 2004. Wyniki badań rozpylaczy dla sprzętu polowego i sadowniczego, 49 ss. https://piorin.gov.pl/cms/upload/akt/Skrotbadanrozpylaczy2004.pdf [dostęp: 20.10.2013].

Pruszyński S. 2011. Integrowana ochrona roślin - wyzwanie dla rolników, służb doradczych i nauki. Zagadnienia Doradztwa Rolniczego 64 (2): 49-65.

Pruszyński S., Mrówczyński M., Pruszyński G. 2008. Ochrona roślin w integrowanej technologii produkcji rolniczej. Probl. Inż. Rol. (59) 1: 87-97.

Rozporządzenia Ministra Rolnictwa i Rozwoju Wsi z dnia 5 marca 2013 r., Dz. U. poz. 415, 5 ss. i z dnia 7 marca 2013 r., Dz. U. poz. 416, 9 ss.

Strutyńska K. 1953. Badania rozpylaczy. Rocz. Nauk Rol. 66-C3. C.I.R - Instytut Mechanizacji i Elektryfikacji Rolnictwa - RNR: 51-74.

Szulc T., Czaczyk Z. 2013. Problematyka określania klas jakości rozpylenia do potrzeb etykiet ś.o.r. s. 124-132. W: Mat. XI Konf. „Racjonalna Technika Ochrony Roślin”. Inst. Ogrodnictwa, Skierniewice, 23 października 2013, 165 ss.

Szymańska B., Baranowski T. 2009. Wpływ kolejności mieszania wybranych fungicydów i zoocydów na właściwości fizyko-chemiczne powstałych cieczy użytkowych. [Effect of the mixing order of selected fungicides and zoocides on physicochemical properties of spraying liquid]. Prog. Plant Prot./Post. Ochr. Roślin 49 (1): 56-60.

Ustawa o zwalczaniu nieuczciwej konkurencji 2009. Dz. U. 2003 nr 153 poz. 1503, tekst ujedn., 11 ss. 